\title{
Medos pandémicos em tempos sombrios e de silêncios ensurdecedores
}

https://doi.org/10.21814/uminho.ed.23.11

\section{Alberto Filipe Araújo}

Alberto Filipe Araújo (ORCID: 0000-0002-4693-8681) é Professor Catedrático aposentado do Instituto de Educação da Universidade do Minho. 
"ulgavam-se livres, e nunca alguém será livre enquanto houver flagelos."

Albert Camus. A Peste, 1947.

"And everybody knows that the Plague is coming. Everybody knows that it's moving fast." Leonard Cohen. Everybody knows, do album I'm your man, 1988.

\section{INTRODUÇÃO'}

O tema que nos propomos desenvolver adquire uma sensação mais estranha se for colocado sob a proteção do deus Pã da mitologia grega, que significa "natureza viva" e também a encarnação do Universo (o Todo), particularmente sob um dos seus atributos, que é o de provocar pânico e terror repentinos pela sua turbulência endógena. Por isso é que Pã é um deus perturbador do espírito e enlouquecedor dos sentidos (parentesco com Dioniso). Perceber-se-á então que os silêncios nestes tempos sombrios e de profunda incerteza não poderão deixar de ser ameaçadoramente ensurdecedores e paradoxalmente monótonos: tempos de horror e de angústia existencial, mergulhados num imaginário apocalítico, senão mesmo escatológico, onde parece que o fim do mundo e das nossas vidas nunca esteve tão próximo. Fica-se com a certeza de que a ideia de fim do mundo (a orientação escatológica) assombra a mentalidade coletiva do nosso

\footnotetext{
1 Muito agradeço aos colegas e amigos Professor Fernando Azevedo e Dr. Hilário de Sousa pela leitura atenta que realizaram da penúltima versão do texto.
} 
tempo² (Boia, 1989; Delumeau, 1997; Dumas-Reungoat, 2001; Foessel, 2012; Ricoeur, 2002, p. 307-477).

2 A este respeito, Michaël Foessel escreve o seguinte: "En dépit de ses origines religieuses, le motif de la fin du monde n'a jamais totalement disparu de l'histoire moderne. (...) Il semble raisonnable de prévoir l'imminence de l'apocalypse à partir du moment où les hommes se sont dotés des moyens de la mettre en ouvre où ils ont fait la preuve de leur absence de scrupule devant les possibilités ouvertes par la technique. Tout se passe comme si la 'fin du monde' cessait d'être le fantasme de quelques avant-gardes apocalyptiques pour devenir une catégorie universelle de l'expérience » (2012, p. 7). De igual modo, o fim das nossas vidas não se pode nem se deve desligar da grave ameaça das alteraçóes climáticas em que a Terra ficará inabitável, parafraseando o título da obra de David Wallace-Wells (2019). A terra inabitável. Uma história do futuro. Consulte-se também AA.VV. (2009). Prophéties, apocalypses \& fins du monde. Courrier International, no 998-999, du 17 au 31 décembre : 45-68. Atente-se igualmente que não se deverão confundir os conceitos de "escatologia" e de "apocalipse": "Les termes d' 'eschatologie' et d' 'apocalypse' sont précisément souvent employés l'un pour l'autre. L'apocalypse évoque essentiellement, aujourd'hui, une catastrophe cosmique, tandis que le mot grec originel apokalupsis signifie simplement 'mise à nu, dévoilement': il s'agit avant tout d'une révélation. (...) Et c'est justement la révélation concernant la fin des temps, les choses finales et dernières (eschata) que devrait recouvrir uniquement le terme d'eschatologie. En réalité, un glissement s'opère entre la réflexion des prophètes - notamment - sur l'avenir (on est encore dans l'histoire) et la réflexion apocalyptique augurée par Daniel dans la tradition juive et qui concerne un avenir hors de l'Histoire. C'est dans cette évolution de la réflexion que le motif de Fin du Monde (lié à la Fin des Temps) trouve sa place. (...) L'eschatologie désigne globalement la 'doctrine des fins dernières' se rapportant à la fin de l'histoire terrestre. Elle interprète donc le temps qui doit s'écouler jusqu'à l'avènement de la fin essentiellement comme la poursuite de l'histoire du salut de l'humanité » (Dumas-Reungoat, 2001, p. 304). No artigo que Michel Hulin escreveu sobre o tema da «Escatologia», na Encyclopédie Universalis, pode ler-se o seguinte: "L'eschatologie est la «science des choses ultimes» (ta eschata, en grec) ou des «fins dernières» de l'homme. Or, comme l'atteste clairement l'histoire des religions, ces fins dernières ont toujours été comprises en deux sens bien différents. D'un côté, c'est le destin post mortem de l'individu qui est en jeu: sa survie, son éventuel jugement dans l'au-delà, son salut ou sa damnation, ou encore sa future réincarnation. De l'autre, il s'agit des événements de la fin du monde: indication des signes annonciateurs de la consommation des temps, description du cataclysme final et annonce du nouvel ordre universel destiné à s'établir sur les décombres de l'ancien», Michel Hulin «Eschatologie», Encyclopadia Universalis [em linha], acedido no dia 15 de junho de 2020. URL: http://www.universalis.fr/encyclopedie/eschatologie/. Neste contexto, não podemos deixar de sublinhar que há toda uma literatura pós-apocalíptica que vale a pena considerar, como é aliás o caso da obra de Mary Shelley intitulada precisamente The Last Man editada em 3 volumes, em 1826. Sobre este assunto, leia-se Chad Harbach (2009). Roman de la fin ou... fin du roman?. Courrier International, no 998-999, 17-31 de dezembro de 2009, pp. 67-68. Sobre a ideia de fim e da mitologia finimundista, leia-se J. Eduardo Franco \& J. Manuel Fernandes. O Mito do Milénio, 1999, p. 25-46. Nesta mesma obra, leia-se a nota 26 sobre o tema do Apocalipse, p. 30-33. Também é de notar que Giorgio Agamben, nas suas "Reflexiones sobre la peste”, escreveu o seguinte: "En el discurso de los medios de comunicación, la terminología tomada del vocabulario escatológico que, para describir el fenómeno, recurre obsesivamente, sobre todo en la prensa estadounidense, a la palabra 'apocalipsis' y a menudo evoca explícitamente el fin del mundo es un indicio de esto. Es como si la necesidad religiosa, que la Iglesia ya no es capaz de satisfacer, buscara otro lugar en el que consistir y la encontrara en lo que de hecho se ha convertido en la religión de nuestro tiempo: la ciencia” (2020, p. 136). 


\section{O título por nós escolhido visa sintetizar quer um estado de espírito, quer uma} vivência da doença provocada pelo vírus conhecido pelo SARS-CoV-2 $2^{3}$, dominados por um medo e pânico ancestrais, envolvidos por sombras e silêncios inconfessáveis. Ainda que não fosse despiciendo debruçar-nos sobre a concetualização do par medo-pânico ${ }^{4}$, preferimos, por agora, salientar que esses sentimentos-limite não só estão

3 Convém desde já referir que SARS-CoV-2 é o nome do novo coronavírus que foi detetado na China, no final de 2019, e que significa "síndrome respiratória aguda grave - coronavírus 2". A COVID-19 é a doença provocada pela infeção pelo coronavírus SARS-CoV-2 que foi identificado pela primeira vez em Wuhan, China, no final 2019. A Organização Mundial da Saúde atribuiu o nome COVID-19, à doença que resulta das palavras "Corona", "Vírus" e "Doença" com indicação do ano em que surgiu (2019). Sobre outros vírus mais recentes, recordem-se o MERS-CoV, que foi identificado em 2012 como a causa da síndrome respiratória do Oriente Médio (MERS), e o SARS-CoV que foi identificado em 2002 como a causa de um surto de síndrome respiratória aguda grave (SARS). Os coronavírus são um grupo de vírus que podem causar infeções nas pessoas, normalmente associadas ao sistema respiratório, podendo ser parecidas a uma gripe comum ou evoluir para uma doença mais grave, como pneumonia.

$4 \mathrm{O}$ que provoca pânico é o facto de o vírus escapar ao nosso conhecimento; como é possível ter surgido uma ameaça biológica que não conseguimos antecipar e dominar a tempo? Por outro lado, o vírus é uma ameaça seletiva, não sendo negligenciável a sua taxa de letalidade, sobretudo nas camadas sociais mais idosas e em pessoas imunologicamente mais vulneráveis. O stresse emocional provocado pela quarentena (solidão, angústia, desespero, abandono, desolação...), pelo medo do desconhecido face a uma pandemia sinistra que espreita a toda a hora pelo momento de abocanhar, qual Escuridão, quais Trevas maléficas, a próxima vítima indefesa, é, na verdade, causador de longas insónias, de elevados índices de ansiedade e de ataques de pânico em cadeia. Neste contexto, a saúde mental de cada uma das potenciais vítimas está no seu nível mais elevado de alerta, bastando, portanto, qualquer motivo, associação, sinal ou índice para suscitar um verdadeiro terramoto, ou tsunami, emocional com todas as consequências que daí advêm. A síndrome da "noite branca”, em que ninguém parece dormir, é um mal coletivo potencializado por uma multitude de incertezas, de toda a ordem, desencadeadas pela pandemia. Confrontados com esta peste viral da COVID-19, «Tous les scénarios hypothétiques ne font qu'alimenter l'incertitude du moment. (...) nous n’avons pas la moindre idée de la façon dont va évoluer cette étrange nouvelle réalité que nous partageons tous», de acordo com as palavras de Douglas Kennedy, romancista americano, publicadas no jornal Le Monde, 30 de maio de 2020. Ninguém parece escapar a esta gigantesca psicose: o pavor real ou fantasmático da contaminação, o medo terrível de ficar agrilhoado a uma cama, qual leito de Procusto, na total incerteza de um dia se poder levantar curado, mas um medo muito maior que todos sacode, é o terrível e feérico medo da morte hedionda sempre diante de nós! Leia-se com muito proveito sobre o tema do SARS-CoV-2 que nos ocupa, a obra editada por Pablo Amadeo, em 2020, intitulada muito sugestivamente Sopa de Wuban (que reenvia ironicamente para uma sopa de morcego que é, aliás, muito apreciada na China) que contou com a colaboração de um conjunto notável de autores, tais como, a título de exemplo, Giorgio Agamben, Alain Badiou, Slavoj Žižek, Byung-Chul Han, entre outros. 
espelhados nos mitos por nós tratados, os do Fausto e do Drácula 5 , como também foram, ainda que numa escala variável, vivenciados por todos aqueles que verteram suas lágrimas amargas no e neste tempo pandémico e de quarentena involuntária. A expressão "tempos sombrios" tem uma história densa, não fosse ela cunhada por Bertolt Brecht no seu poema "An die Nachgeborenen” (1939 - "À posteridade" / Aos que vierem depois de nós”): "Wirklich, ich lebe in finsteren Zeiten!” ("Realmente, eu vivo em tempos sombrios!” - tradução nossa). Também foi usada por Hannah Arendt para justamente intitular uma das suas obras - Homens em Tempos Sombrios (1960).

5 Naturalmente que o mito de Frankenstein teria aqui o seu lugar cativo, mas por razóes de encomia textual optamos tão-somente pelos mitos enunciados. O mito de Frankenstein é um mito literário criado por Mary Shelley com a sua obra intitulada Frankenstein ou o Prometeu Moderno (Frankenstein: or the Modern Prometheus, no original em inglês, publicado em 1818). Este romance de terror gótico, com inspiraçôes do movimento romântico, é mais conhecido simplesmente por Frankenstein. Como o próprio subtítulo indica trata-se de um mito que, por sua vez, se filia num outro mito - o de Prometeu: "La figure moderne de Prométhée cristallise les rêves des 'Lumières'. Cette figure se précise avec Goethe. Dans le Prométhée, de Goethe, Prométhée n'est plus une divinité primordiale, c'est l'homme conçu comme génie créateur de lui-même, qui n’a plus besoin de dieux et assume lui-même son destin. Les incarnations prométhéennes sont très nombreuses au XVIII et au XIX siècle, dans le théâtre et la littérature. // Deux éléments y dominent: l'élément luciférien: Prométhée est fils de lumière. C'est par la raison et par la science que l'homme se délivre et inaugure le nouvel âge. Prométhée est une des grandes figures mythiques de l'émancipation humaine; l'élément démiurgique: la technique conçue comme instrument de transformation des conditions d'existence des hommes» (Sironneau, 1980, p. 21). Jean Brun, na sua Philosophie de l'histoire, escreve: «La technique n'a-t-elle pas fait de l'homme un nouveau Prométhée voleur de feu, pourquoi n'en ferait-elle pas aussi un Prométhée bâtisseur du refuge suprême? (...) Ainsi, l'héritage hégélien a pu être repris, 'revu et corrigé', par tous ceux qui virent dans cette philosophie de l'histoire un instrument utilisable pour faire définitivement du 'Vous serez comme des dieux' le manifeste révolutionnaire d'une histoire et d'une politique prométhéennes grâce auxquelles l'homme deviendrait son propre Créateur et son propre Sauveur. (...) le 'Vous serez comme des dieux' s'allie au rêve prométhéen et faustien de la reconstruction de la Terre» (1990, p. 76, 198-199, 235). É, portanto, neste contexto dominado pelo mito de Prometeu que o mito de Frankenstein deverá ser compreendido. Frankenstein, a Criatura, tomou o nome do seu criador que não só o construiu à luz das técnicas científicas conhecidas no final do século XVIII e meados do século XIX, como também lhe emprestou a simbólica prometeica. É deste modo que se compreende o subtítulo do romance - ou o Prometeu Moderno. Frankenstein é um mito ao serviço de um projeto humano de autocriação e de auto-divinização que procura transformar o destino do homem e colocá-lo ao mesmo nível dos deuses. "Vós sereis como deuses”! (Sironneau, 2000, p. 92-103). Para uma panorâmica do mito de Frankenstein, onde aliás abunda uma bibliografia considerável, consulte-se Guimarães, A. R., Araújo, A. F., Ribeiro, J. A. \& Almeida, R. de (2015). Olhares sobre Frankenstein. [Bibliografia final] 
Se a precedermos do oximoro "silêncios ensurdecedores", então o nosso título já indica que a nossa visão do mundo, assim como a grande apreensão que experienciamos face ao tempo pesado e languidamente sombrio que estamos a viver, comunga de uma visão pessimista senão mesmo trágica.

O fio condutor, a nossa bússola que nos orientará ao longo deste estudo é, por um lado, o terrível medo de morrer que o humano experiencia no transfundo da sua alma arquetípica (que na terminologia junguiana corresponde ao inconsciente coletivo), e, por outro lado, o desejo que tem de prolongar a sua vida pelos corredores eternos do tempo aqui na terra: uma imortalidade desejada e ambicionada num corpo eternamente jovem e belo. Neste contexto, o nosso estudo dividir-se-á em quatro partes. Começaremos por revisitar os mitos de Fausto e de Drácula: o primeiro passando de temente a Deus a adorador de Satã em troca de uma juventude eterna para alcançar o amor e uma sabedoria sem fim, o segundo, já filho das trevas satânicas, que ansiava ser imortal no mundo dos homens, entre outros desígnios, para ser amado. De seguida, evocaremos os temas da peste e da morte a propósito do Sétimo Selo (1957) de Ingmar Bergman que, aliás, é um filme que em muito ultrapassa esses mesmos temas ou não fosse a crise de fé em Deus vivida pelo Cavaleiro uma das suas questóes mais relevantes. A terceira parte é dedicada, na companhia de Albert Camus, à perca do nosso mundo, quando males terríveis, como são os casos mais variados de peste, nos assolam sem dó nem piedade. Por último, sob o signo de os “jogos amargos da recordação" (Albert Camus), teceremos algumas reflexões sobre uma peste virulenta que nos tem assombrado tão cruelmente nestes últimos tempos das nossas vidas. Resta-nos, por fim, esperar que não tenhamos que dar razão a Jim Jamurch, quando no seu último filme, The Dead don't Die (Os Mortos não Morrem-2019), um dos seus personagens repete insistentemente: "Isto vai tudo acabar mal"!

\section{DO MEDO DA MORTE E O FASCÍNIO PELA IMORTALIDADE: FAUS- TO E DRÁCULA COMO COMPANHIA}

O medo de morrer contaminado pelo novo coronavírus, designado SARS-CoV-2, gera ansiedade, stresse emocional, pânico, uma angústia infinda. $\mathrm{O}$ medo de ser infetado, com as consequências funestas que daí podem advir, faz-se inexoravelmente 
acompanhar de um coro de silêncios ensurdecedores que deixa as suas vítimas não só paralisadas como também pálidas, quase como mortas-vivas, esvaziadas de amor e de afetos. Neste sentido, compreende-se o horror, até mesmo o terror, sentido pelas vítimas da peste que assistimos no Fausto de Murnau, assim como não esquecemos o que as vítimas do Drácula viviam na hora fatal, quando os dentes caninos deste se cravavam nos seus pescoços transidos de um pavor insano. Todo o horror se casa com um silêncio contrariado, imposto, sempre recusado, sempre exorcizado, por aqueles e aquelas que teimam em viver apressadamente e obcecados pela juventude eterna que já é outro modo de falar de imortalidade. E quando confrontados com um revés imenso, corporizado por um morto-vivo, correm, sob o espetro de um medo telúrico e arrepiante, a confinar-se fantasmaticamente num algures inquietante. Toda essa correria tende a acontecer num ritmo dolorosamente lento e já há muito esquecido pela voracidade de vidas corridas, quantas vezes sem destino, despidas de história(s) sentida(s). Neste contexto, sentimos as sombras iluminantes de Fausto e de Drácula, ambos companheiros de noites mal dormidas e sobressaltadas com pesadelos diabólicos. Acreditem ou não, eles andam por aí, pela simples razão de que nos habitam no transfundo do nosso inconsciente coletivo na feliz designação de Jung (1938, p. 9-33, 1965, p. 42-61).

\section{1 Fausto: juventude eterna e imortalidade}

No filme Faust - Eine Deutsche Volkssage (Fausto - Um Conto Popular Alemão 1926) de F. W. Murnau, o Arcanjo pergunta ao Diabo: "Volta! Espera! Por que açoitas a humanidade com a Guerra, a Peste e a Fome?!” A "Peste” que agora caiu sobre nós aparece no nosso imaginário coletivo, moldado pelas mitologias do fim do mundo com todo o seu cortejo de sinais escatológicos que as acompanham, sob a obsessão da morte, do sofrimento e da dilaceração. A barca de Caronte está sempre pronta para transportar os corpos amontados para um Hades sem esperança porque sem retorno: "Os portais das trevas estão abertos, e as sombras dos mortos vagueiam pela Terra...” lê-se no Faust de Murnau. Todo um conjunto de penas inimagináveis é cruelmente instigado por um 
dos quatro cavaleiros do Apocalipse - o mensageiro da Peste: "Quando abriu o quarto selo, ouvi a voz do quarto vivente dizer: 'Vem' (Ap. 4, 7). Olhei e vi um cavalo esverdeado; e o que montava tinha por nome Peste; seguiu-o Hades. Foi-lhe dado poder sobre a quarta parte da terra, para a fazer perecer pela espada, pela fome, pela peste e pelas feras da terra (Ap. 20, 14; Ez. 14, 21; prov. 5, 5; Jer. 15, 2)” (Ap. 7-8).

Também Fausto, no filme de Murnau, se confrontou com a impossibilidade de encontrar cura para a peste demoníaca, em tudo fazendo lembrar a Peste Negra, que alastrava, qual lava vulcânica, rapidamente por toda a cidade: "Um terror mortal e o medo da morte tomavam conta da cidade (...) em questão de dias, metade da cidade estava agonizando (...) A epidemia devastava rapidamente” (F. W. Murnau (1926). Fausto). Impotente, Fausto entra num pânico tão absolutamente desesperado por considerar que "nenhum conhecimento ajudará" e por "tudo ser vaidade” que acaba, num ato tresloucado associado à sua perda de fé, por entregar sua alma ao próprio Diabo: "Não há salvação, nenhuma fé ajudará". Uma entrega que ficou conhecida pela perdição ou danação de Fausto. O Diabo, personificação do Mal, tudo lhe promete com a condição de Fausto a ele se submeter: o célebre Pacto com Mephisto, que durará toda a eternidade, e que Fausto deve assinar com o seu próprio sangue, simbolizando a sua própria escolha entre o Bem e o Mal! Uma assinatura que simboliza já a sua submissão ao próprio Satã em troca do "poder e da glória do mundo", além da promessa da eterna juventude que já é em si-mesma o símbolo do prazer e, muito particularmente, da própria vida! Fausto apaixona-se perdidamente pela bela Gretchen já na pele de um jovem galã: Fausto ao contemplar a imagem de uma bela donzela pergunta a Mephisto: "Isso

6 O Apocalipse foi escrito pelo apóstolo João (Ap. 1-22), o mais jovem dos discípulos de Cristo, durante o seu exílio na ilha de Patmos. Sozinho, sujeito a visóes alucinantes, escreveu esta obra que relata o fim dos tempos. Numa linguagem épica, fala dos Quatro Cavaleiros simbólicos que espalharão o terror nessa época terrível: a Guerra, a Fome, a Peste e Morte. O Apocalipse de S. João molda o imaginário escatológico e mesmo milenarista (AA.VV., 1986). Leia-se igualmente o artigo de Juan Luis Cebrián intitulado Apocalipse now onde se pode ler o seguinte: "Não sabemos ainda quase nada sobre o vírus, e sabemos muito pouco sobre o futuro do mundo, mas, sim, podemos estar certos de que será muito diferente - e pior. Não se trata de anunciar o apocalipse now, ainda que comecemos a ver a cara dos cavalos da peste, a fome, a guerra e a morte que anunciam na Bíblia o fim dos dias. Temos os meios e as ferramentas para evitar uma catástrofe maior do que a que vivemos. Mas também é necessária a vontade de o fazer" (Diário de Notícias, 26 de maio de 2020, https://www.dn.pt/edicao-do-dia/ 23-mai-2020/apocalipse-now-12228445.html?target=conteudo fechado. 
é a morte?" E Satã responde-lhe: "É a vida, Fausto, te seduzindo... com a formosa imagem...da sua juventude!" e depois promete-lhe prazer: "Prazer é tudo!” algo que Fausto nunca tinha experimentado ou sequer sentido até esse momento! Fausto exclama: "Sou muito velho!". Ao ouvir isto, o Diabo oferece-lhe a felicidade suprema: a "Juventude!" que também é já uma outra maneira de prometer-lhe a imortalidade. E Fausto cede, abraçando-a sequiosamente.

Uma Peste saída das suas mãos que se abate inexorável e impiedosamente sobre uma humanidade desamparada, ainda que alimentada pelos sonhos de que a imortalidade seria para um “aqui” e um “agora”! Uma miríade de sonhos tecidos por toda uma mensagem "transhumanista e pós-humanista" que a literatura e os filmes dedicados às

\footnotetext{
7 Sobre o tema do "transhumanismo e do pós-humanismo", veja-se, entre outras, a obra de Luc Ferry. La révolution transhumaniste: comment la technomédecine et l'uberisation $d u$ monde vont bouleverser nos vies, 2016 e os artigos de Anselmo Borges, publicados no Diário de Notícias, em 17, 24 e 31 de março, dedicados ao trashumanismo e pós-humanismo. Confere, por exemplo, http://hypescience.com/fonte-da-juventude-\%E2\%80\%9Ceterna\%E2\%80\%9D-e-descoberta/ onde se lê que o pesquisador de Harvard Ronald A. DePinho descobriu uma forma de reverter os efeitos da idade. O título, confessamos, é sensacionalista: "Fonte da Juventude 'eterna' é descoberta". Veja-se igualmente um artigo publicado no jornal Expresso, datado de 5.05.2014, intitulado "Transfusóes de sangue jovem podem inverter envelhecimento", em http://expresso. sapo.pt/sociedade/transfusoes-de-sangue-jovem-podem-inverter envelhecimento=f868494. Outro artigo, referindo-se ao mesmo tema, intitula-se "Transfusão de sangue jovem pode ser o caminho para a juventude eterna, em http://gizmodo.uol.com.br/transfusao-de-sangue-jovem-pode-ser-o-caminho-para-a-juventudeeterna/. Havendo mesmo um artigo, sobre o mesmo tema, onde a palavra vampiro figura: "Vampiro Terapia' poderia reverter o envelhecimento, se os cientistas realizarem em paciente idoso transfusão de sangue jovem", em http://illuminatielitemaldita.blogspot.pt/2014/05/vampiro-terapia-poderia-reverter-o.html. Ultimamente apareceu um novo artigo intitulado "Cientistas mais perto de descobrir droga anti-envelhecimento", in: http://24.sapo.pt/atualidade/artigos/cientistas-mais-perto-de-descobrir-droga-anti-envelhecimento, acedido em 23 de março de 2017. Lembramos o filme de Darren Aronofsky, "The Fountain - O Último Capítulo" (2007) onde o tema da "Fonte da Juventude" é o ponto de partida para o cientista Tommy Creo procurar a cura do cancro que está a matar a sua esposa. O título do filme no Brasil é mais sugestivo miticamente - "Fonte da Vida”. Sobre o imaginário da criação de um novo ser artificial isento de doenças e mesmo da morte, com a mitologia messiânica da imortalidade que lhe está associada, veja-se Jean-Jacques Wunenburger, 2016, p. 113116. Esta nova humanidade biotecnológica, do ponto de vista do seu imaginário, identifica-se mais com os mitos de Fausto, de Frankenstein e de Drácula do que com os mitos de Prometeu e de Golem. Trata-se de novos seres que já pouco ou nada têm a ver com os "velhos" robots, cyborgs que são como objetos que sintetizam matéria e inteligência artificial, vida contínua por oposição a morte carnal (2016, p. 112).
} 
figuras míticas do Fausto, do Drácula e do Frankenstein ${ }^{8}$ de alguma maneira já anunciavam ao fazerem da imortalidade e da eterna juventude as suas obsessóes preferidas. Sob o signo do "pacto", que o medonho e cínico Mephisto fez Fausto assinar com sangue, a imortalidade aconteceu e o mesmo acontece com "o batismo de sangue do vampiro" que Drácula opera com as suas inocentes vítimas, recordando, por exemplo, Lucy e Mina! Pelo batismo vampírico os mortos-vivos vivem para sempre, tornam-se imortais e as suas formas permanecem jovens (o mitologema da "eterna juventude"). Curiosamente, desde o momento que assinou o "pacto" com o seu sangue, também Fausto, de alguma maneira, se transformou numa espécie de "morto-vivo" de filho das trevas demoníacas.

\subsection{Drácula: horror e imortalidade}

Uma espécie de silêncio terrífico que, paradoxalmente, em muito se assemelha ao curso temporal silencioso que dista dos dentes pontiagudos e flamejantes de Drácula ao pescoço de Lucy ou de Mina: uma mordidela sangrenta porque sádica e com o seu quê de erótica. Trata-se, na verdade, de uma das cenas mais emblemáticas do romance de Bram Stoker (1897) e que não resistimos a transcrever na medida em que ela nos dá uma ideia, entre o real e o ficcional, do modo como o vírus age frente às veias inocentes e desprotegidas de cada um dos expostos, sempre tão atordoados como apavorados. Por mais estranho que possa parecer, as vítimas, ao ficarem como que hipnotizadas, não fazem nenhuma tentativa para se furtarem, antes parecendo deliciar-se orgasticamente por oferecerem a sua virgindade ao poder viril do monstro, sempre sequioso de sangue e de mais sangue fresco brotado incessantemente de carnes rasgadas: "E a senhora

\section{Consulte-se a nota 4 .}

9 O romance de Stoker tal como é sobejamente conhecido inspirou filmes notáveis sobre o vampirismo ou sobre o Drácula. Recordemos, tão-somente, os clássicos seguintes: Nosferatu, o Vampiro de Friedrich Wilhelm Murnau (1922), Drácula de Tod Browning (1931), O Horror de Drácula de Terence Fischer (1958), O Vampiro da Noite de Werner Herzog (1979) e o Drácula de Francis Ford Coppola (1992). No filme de Herzog, a ida de Drácula para Wismar (Alemanha do século XIX), leva consigo a peste negra que rapidamente assola toda a cidade recordando cenas marcantes da peste do Fausto de Murnau. Os seus habitantes, confrontados com tantas mortes e sofrimentos, festejam os seus últimos dias. Para maiores esclarecimentos sobre a presença do vampiro no ecrã, leia-se Gilles Menegaldo. O ecrã negro dos nossos terrores, 1998, p. 91-117. 
[Mina], a mais bem-amada de todos eles, é agora minha [diz Drácula]: é carne da minha carne, sangue do meu sangue, parente dos meus parentes, minha adega abundante durante algum tempo, e mais tarde minha companheira e ajudante" $\left(2014\right.$, p. 312) ${ }^{10}$. Não podemos deixar de nos impressionar como esta passagem dá tão bem conta, fisiológica e realisticamente, do modo como o vírus age quando se apodera de um infeliz. Metaforicamente, pensamos que outros diriam: é assim que o vírus se comporta, faz do infetado o seu parente, a sua "adega abundante" e também um seu cúmplice sinistramente ativo sem muitas vezes disso se dar conta. Aquele que por si é mordido passa a ser seu ajudante devoto na contaminação de um outro infeliz que com ele inadvertidamente se cruzou num lugar e num tempo errados. Mais, e é preciso reafirmá-lo, enquanto somos tão-somente vítimas mortais à mercê de coronavírus-vampiro, este, tal como Drácula, "pode viver durante séculos” (Stoker, 2014, p. 342) e assim sendo a desgraça e o infortúnio humanos são a perder de vista. $O$ vírus assim se dissemina e se replica obsessivamente num crescendo pantagruélico que leva os infelizes contaminados a abraçarem, por um lado, o medo e o pânico e, por outro lado, a sofrerem de uma congestão fastidiosa:

os lábios vermelhos entreabertos [os de Drácula], revelando os dentes brancos e aguçados e os olhos vermelhos (...) Com um sorriso trocista, pousou-me [trata-se de Mina mulher de Jonathan] uma das suas mãos no ombro e, segurando-me com força, desnudou-me a garganta com a outra, dizendo: 'Primeiro, um pequeno refresco como recompensa dos meus esforços. É melhor ficar imóvel. Não é a primeira vez, nem a segunda, que as suas veias me acalmam a sede!' Eu já estava atordoada e, por muito estranho que pareça, não queria fugir dele. Suponho que isso faz parte do seu terrível poder, quando toca na sua vítima. E, oh, meu Deus, meu Deus, tem piedade de mim! Ele encostou à minha garganta os seus lábios asquerosos! (...) - Senti que as forças me abandonavam e estava quase a desfalecer. Não sei quanto tempo aquela cena horrível durou, mas pareceu ter passado

\footnotetext{
10 O mito de Drácula mergulha-nos no fundo dos nossos fantasmas, interroga-nos de modo a atormentar-nos porque ele mexe, como nenhum outro mito moderno, com a nossa carne fraca e prenhe de desejo, mas sobretudo interpela a nossa existência efémera no confronto da sua eternidade de vampiro que não se deixa medir pelo Cronos inexorável e inextinguível da existência: "Mórbida encarnação do indescritível, Drácula mergulha-nos no 'coração do fantástico' (...) Verdadeiro negativo da nossa existência revela-se, no entanto, sempre que se alimenta dos nossos fantasmas, mais do que do nosso sangue” (Marigny, 1999, p. 69).
} 
muito tempo até que ele retirou a sua boca horrível, asquerosa e zombeteira. $\mathrm{Vi}$ gotejar dela sangue fresco! (...) Nesse momento, [Drácula] abriu a camisa com as suas longas e afiadas unhas abriu uma veia no peito. Quando o sangue começou a jorrar, prendeu as minhas mãos com uma das dele, segurando-as com força, e com a outra agarrou-me o pescoço e obrigou-me a encostar a boca à ferida, de tal maneira que ou eu sufocava ou tinha de engolir algum do ... Oh, meu Deus! Meu Deus! Que fiz eu? Que fiz eu para merecer destino semelhante, eu que tentei permanecer no caminho reto durante todos os dias da minha vida? Deus tenha piedade de mim! (...) Então começou a esfregar os lábios [é de Mina que se trata], como que a limpá-los da contaminação (2014, p. 311-312) ${ }^{11}$.

Nestes tempos sombrios, todos somos Lucy ou Mina, fragilizados, expostos a um vampiro simultaneamente distante mas cruelmente tão próximo, como é o caso deste coronavírus tão nano molécula, aparentemente tão frágil, que se desvanece com a espuma de um mero sabão vulgar, mas impiedosamente tão sinistro como malévolo ${ }^{12}$. O medo e o pânico de por ele ser infetado torna-o numa espécie de génio maléfico que,

11 Drácula e o seu mito, no alto da sua sombra inumana encarnando o mal absoluto, ensinam-nos sobre aquilo que há de mais profundo em nós: as nossas inquietaçôes, os nossos medos mais enraizados, como o da morte, e sobre as nossas aspirações, mesmo aquelas mais inconfessáveis.

12 António Guterres, numa entrevista concedida à RTP no dia 8 de junho de 2020, afirmou que a grande conclusão que se poderia retirar da pandemia era que se deveria constatar "a enorme fragilidade do nosso mundo, das nossas sociedades, do planeta. Trata-se de um vírus microscópico e esse vírus pôs-nos de joelhos. Ao mesmo tempo, sabemos que somos extremamente frágeis às alteraçôes climáticas, à não proliferação nuclear - vemo-la ameaçada todos os dias - e que no ciberespaço se passam muitas coisas que não controlamos e que póem também em risco a nossa vida quotidiana” (Diário de Noticias, https://www.dn.pt/poder/antonio-guterres-o-mundo-nao-esta-preparado-para-a-atual-crise-12292385.html). Neste sentido, o Cardeal D. José Tolentino Mendonça, na sua intervenção no quadro das "Comemorações do Dia de Portugal, de Camões e das Comunidades Portuguesas" (10 de junho de 2020), falou da necessidade e da importância de "implementar-se um novo pacto ambiental”: "A pandemia veio, por fim, expor a urgência de um novo pacto ambiental. (...) Num dos textos centrais deste século XXI, a Encíclica Laudato Si (2015), o Papa Francisco exorta a uma 'ecologia integral', onde o presente e o futuro da nossa humanidade se pense a par do presente e do futuro da grande casa comum. Está tudo conectado”. Neste contexto, leia-se igualmente, além da Encíclica papal atrás citada (18 de junho de 2015), a obra de Félix Guattari. Les trois écologies. Paris: Éditions Galilée, 1989. 
pela sua estrutura e existência, se assemelha à de um morto-vivo ${ }^{13}$ como se de um vampiro, sob forma de morcego ${ }^{14}$, qual Drácula (Bram Stoker, 1897) se tratasse. Os mortos-vivos, quando imortais, fazem novas vítimas e o seu número não para de aumentar, tal como acontece com o coronavírus. As suas vítimas contaminadas, muitas sem disso terem consciência, contaminam outras vítimas e todo este pestilento cortejo dissemina o mal:

Quando se tornam assim [Van Helsing refere-se ao poder dos mortos-vivos], vem com a mudança a imortalidade; não podem morrer, mas devem continuar através dos tempos acrescentando novas vítimas e multiplicando os males do mundo, pois todos os que morrem como presas dos mortos-vivos tornam-se, eles próprios, mortos-vivos e, por sua vez, atacam os seus semelhantes. (...) pode ser morcego, como a senhora Mina o viu da janela de Whitby, como o amigo

13 Consulte-se o artigo de Sarah Kaplan, William Wan \& Joel Achenbach. No Drácula de Bram Stoker, como é conhecido, há muitas referências ao vampiro sob forma de morcego: "Entre mim [Mina Murray] e o luar, um grande morcego voava em círculos. (...) Depois, acompanhei [Dr. Seward] o olhar do doente, que estava voltado para o céu iluminado pela Lua, mas via apenas um grande morcego, que voava silenciosa e fantasmagoricamente rumo ao poente. (...) Aproximei-me da janela e olhei para fora, mas não vi nada, a não ser um grande morcego que evidentemente tem estado a bater com as asas nos meus vidros [Lucy Westenra]. (...) o jardim estava iluminado pelo luar e vi que o barulho era feito por um grande morcego, que voava em círculos, sem dúvida atraído pela claridade embora muito ténue, e que de vez em quando batia na janela com as suas asas [Dr. Seward]. (...). Lamento muito tê-la assustado [diz o Sr. Morris à senhora Harker]. Mas o facto é que enquanto doutor estava a falar, um grande morcego veio sentar-se no peitoril da janela” (2014, p. 102, 118, 154, 171 e 261), assim como os vampiros, no mesmo romance, recebem o nome de "mortos-vivos": "Ela [Lucy] morreu em transe, e também em transe é uma 'morta-viva'. De facto, começava a sentir repulsa na presença daquele ser, daquela morta-viva, como lhe chamara Van Helsing, e a detestá-lo [palavras de John] (...) - A menina Lucy está morta, não é verdade? Sim! Por conseguinte, não é possível fazer-lhe mal; mas se não está morta... [palavras de Van Helsing] (...) - Não disse que estava viva [Van Helsing referindo-se à Lucy], meu amigo. Não o creio. Apenas digo que é possível que seja uma morta-viva” (2014, p. 216-217 e 222). Veja-se igualmente o artigo do Público, de 24 de março de 2020, https://www.publico.pt/2020/03/24/ciencia/noticia/coronavirus-nao-vivo-tao-dificil-matar-1909146: “O coronavírus não está vivo. É por isso que é tão difícil de matar. Há algo de génio maléfico na forma como este coronavírus funciona: encontra terreno fértil em humanos sem que eles percebam. É poderoso e mortal em alguns, mas leve o suficiente noutros para escapar à contenção. Este é um retrato científico do que os cientistas enfrentam”.

14 Consulte-se o artigo "COVID-19: OMS confirma que origem provável do vírus é morcego chinês", Notícias Ao Minuto, 21/04/20, https://www.noticiasaominuto.com/mundo/1461907/COVID-19-oms-confirma-que-origem-provavel-do-virus-e-morcego-chines. 
John o viu voar da casa aqui ao lado e como o meu amigo Quincy o viu à janela da menina Lucy. [palavras do Dr. Van Helsing] (...) Não o vi, mas vi um morcego levantar voo da janela do quarto de Renfield e voar em direção a oeste. (...) Deve ser levado por alguém [refere-se ao Drácula]. Isto é evidente, pois se tivesse o poder de se movimentar sozinho como gostaria de fazer, fá-lo-ia quer como homem, ou lobo, ou morcego, ou de qualquer maneira." (2014, p. 231, 259, 310 e 382-383).

Se assim, à primeira vista, o SARS-CoV-2 parece tão frágil, não deixa, contudo, de ser tão terrivelmente ameaçador, como tão teimosamente invisível, e causar um horror indescritível: um horror parecido com aquele que Drácula suscita nas suas pobres vítimas, assim como aquele mesmo horror que Mina vampirizada suscitava aos olhos do Dr. Seward, de Arthur, de Quincey e de Van Helsing (2014, p. 215, 227, 229 e 233). Um hóspede tão monstruoso como indesejado que ousa aparecer sem ser convidado e, num tom jocoso, ousando mesmo sentar-se no nosso corpo, banqueteando-se ${ }^{15}$ e deliciando-se sadicamente com a nossa dor, com a nossa infelicidade, com os nossos medos mais ancestrais. Um temível vírus que se faz de adormecido para o julgarmos morto e quando aparentemente morre, parece, aos olhos dos mais distraídos, que dorme. Um coronavírus que se senta e adormece dentro de nós, corroendo as nossas entranhas, esventrando-nos lentamente num silêncio, também ele ensurdecedor: silêncio de chumbo, "lutuoso", longo, demasiado longo que se confunde com uma eternidade agora tão próxima de realizar-se num presente eterno. Um vírus que, à semelhança do Drácula, tem todo o tempo do mundo para infetar as suas vítimas expostas ao mal da doença que corrói e esventra, não só o seu corpo como também a sua própria alma:

a mim [Drácula] que dirigi nações e conspirei por elas e por elas lutei, centenas de anos antes de eles terem nascido, eu estava a sabotá-los. (...) No entanto, ele [Drácula] deseja triunfar e um homem que tem diante de si vários séculos pode dar-se ao luxo de esperar e de agir com lentidão, Festina lente [“Apressa-te devagar”] pode muito bem ser o seu mote. (...) Ando [diz Drácula] pela terra há

15 Reenvia-nos para as palavras de Van Helsing que se referindo ao Conde Drácula diz “- O meu amigo [Dr. Seward] esquece-se de que a noite passada ele desfrutou de um extraordinário banquete [na noite anterior tinha sugado abundantemente o sangue de Mina] e que irá dormir até tarde?” (2014, p. 321). 
séculos e o tempo está do meu lado. (...) - Porque - respondeu ele solenemente [Van Helsing] - ele [o Drácula] pode viver durante séculos e a senhora [Mina] é apenas uma mulher mortal. (...) pode [o Drácula] optar por dormir durante um século (...) (2014, p. 312, 329, 333, 342 e 387).

Uma peste que nos deixa sem chão e sem mundo, desalmados e à mercê das suas garras e dentes caninos sem já contar com o seu mais profundo desprezo: "Quando o conde nos viu, [disse Van Helsing] um esgar horrível perpassou-lhe no rosto, mostrando os dentes caninos, longos e afiados, mas o sorriso maligno desvaneceu-se rapidamente, sendo substituído por uma expressão fria e de profundo desdém” (2014, p. 332). Como uma alma danada, essa sinistra monstruosidade vampírica, nem viva nem morta, arranca-nos a(s) nossa(s) esperança(s) empalidecida(s) ̀̀(s) qual(ais) teimamos obstinadamente em nos agarrar à maneira dos náufragos, fazendo lembrar o Robinson Crusoe, de Daniel Defoe (1719), a fim de não enlouquecermos de uma dor tão desesperada como impotentemente desastrada e patética de tão horrorizada.

\section{PESTE E MORTE: ALGUNS ENSINAMENTOS DO SÉTIMO SELO(1957) DE INGMAR BERGMAN}

No ponto anterior, referimos Crusoe de Defoe, mas agora preferimos antes recordar Um Diário do Ano da Peste (A Journal of the Plague Year - 1722) do mesmo autor que, num misto de jornalismo e de ficção, nos brinda com uma reconstituição do fatídico verão de 1665, quando a peste bubónica, também conhecida pela Grande Peste de Londres (1665-1666), assolou a cidade, tendo vitimado entre 75.000 e 100.000 dos seus habitantes, ou seja, um quinto da população, não esquecendo também, en passant, a peste de Marselha, de 1720 . O autor falava desta peste como uma calamidade terrível, que se estendia com tanta rapidez que se tornava quase impossível detê-la, que com ela trazia desolação, abatimento e desespero: uma calamidade que assolava "toda a cidade e cuja gravidade, como se não bastasse em si mesma, foi talvez muito aumentada pelos meus receios, tanto quanto pelos dos outros” (1966, p. 30). Mais adiante assim escrevia: "Os gritos de mulheres e crianças nas janelas ou nas portas das casas onde os seus familiares mais queridos estavam a morrer ou já mortos eram ouvidos com tanta frequência que eram suficientes para trespassar o coração mais forte do mundo. Em 
quase todas as casas se ouviam lágrimas e lamentos, especialmente nos primeiros dias da epidemia, porque nos últimos tempos os corações se endureciam e a morte tinha-se tornado uma visão tão comum que ninguém se preocupava demasiado com a perda de um amigo, na expectativa de sofrer a mesma sorte em qualquer momento" (1966, p. 37-38). Não podemos deixar de constatar que a atualidade das descriçôes por si registadas ao longo do seu Diário muito nos impressionam, não só pelo seu realismo cruel como pela sua semelhança com tudo aquilo que estamos tão dilaceradamente a viver ${ }^{16}$, prisioneiros de uma impotência, tão trágica como patética, que nos aproxima do desespero fáustico que adiante evocaremos.

O deus Pã faz o seu regresso. Drácula acompanha-o. Um "admirável mundo novo" (recordando o distópico romance de Aldous Huxley) parece abrir-se diante de nós, uma peste avassaladora inunda-nos até aos lugares mais recônditos dos nossos corpos que até há pouco tempo desposavam as glórias vãs de imortalidades terrestres anunciadas por um Frankenstein, filho pródigo de sonhos transhumanistas tresloucados. Novos deuses imortais na terra, fazendo inveja a um já pálido e quase esquecido Prometeu, cantada por uma humanidade fáustica, condenada a morrer ingloriamente nas garras pontiagudas de um monstro, qual Hidra de Lerna, diabólico e petrificado. E, mais uma vez, um silêncio ensurdecedor acontece e percorre aqueles que esperam a morte, bem como todos aqueles que para ela se preparam sem disso o saberem. E tantos outros que se lhes sucederão numa relação irreal, fantasmagórica com a vida, numa espera desesperadamente angustiante de desconhecerem o dia e a hora da chegada do vivo-morto que sempre chega insidiosamente. E haverá algo de mais horripilante do que saber que o hediondo coronavírus, que nos consome literalmente, veio para ficar entre nós à semelhança de Drácula e da sua corte vampiresca? Realmente podemos nós afirmar que a nossa condição humana, como o profetizou Günther Anders (2011 - Vol. I e II), também ela já em estado de obsolescência, não mais se livrará deste SARS-CoV-2

\footnotetext{
16 Na verdade, ao longo de A Journal of the Plague of Year (1722) há todo um relato de situações, de factos, de avisos, de recomendaçóes, de sofrimentos, de medos, de choros, de vivências trágicas, de gritos estridentes, de mortes alucinantes na sequência da peste que em muito se assemelha a tudo aquilo que temos assistido, vivido e sofrido ao longo destes tempos funestos e enlutados provocados pela pandemia do coronavírus SARSCoV-2. Sobre a atualidade pungente do relato feito por Daniel Defoe na sua obra, entre muitos exemplos que poderíamos citar, contentar-nos-emos, tão-somente, em remeter o leitor para as pp. 219-220, 234-38.
} 
pelo facto de a Morte usar esse coronavírus como uma das suas peças de xadrez favoritas para dar os seus xeques-mate às pobres vítimas indefesas?

Todos somos peregrinos, alguns já tristemente moribundos, numa vida tornada num Hades sombrio e desolador, qual terra de cinzas, silenciosamente desencarnada. Tudo nos parece estranhamente irreal. Exceto o medo, que nos atravessa cruelmente, mesmo que imaginariamente, fazendo-nos temer sermos as próximas vítimas de uma Besta sanguinária. Ao medo junta-se igualmente o pânico, que também nos invade e que paulatinamente nos prepara para provarmos um medo ainda maior porque sabemos que a Besta, mais cedo ou mais tarde, nos vencerá na última partida de xadrez que com ela somos forçados a jogar e a seguir nos devorará. Um jogo que evoca uma das cenas mais emblemáticas da filmografia bergmaniana no seu filme O Sétimo Selo $(1957)^{17}$, em que o cavaleiro joga xadrez com a própria morte a fim de ganhar mais um tempo de vida. A sua foice erguida, o seu rosto esbranquiçado e amarelecido por ter já atravessado séculos de existência, olham-nos concupiscentemente enquanto o desejo aparece refletido nos seus olhos flamejantes e anunciadores de terrores inusitados. E assim a Morte silenciosa, tão temida como admirável, é anunciada contra a nossa vontade pela simples razão de que todos, tal como Fausto confessou, temos um enorme e inequívoco medo de morrer. Por mais pactos que façamos com o Diabo, todos sabemos que não somos imortais, mas todos perfilhamos a ilusão dessa mesma imortalidade onde a nossa hora será sempre adiada, seja por um pacto sonhado ou por uma jogada do Rei.

E aqui chegamos ao $\mathrm{mal}^{18}$ - tabu dos tempos hedonistas, individualistas, relativistas, consumistas que são os nossos e em que a tecnociência, baseada num progresso tecnológico utópico, promete a salvação e a imortalidade na terra - simbolizado pela peste, enviada pelo Diabo à terra, assustadoramente filmada por Murnau no seu Fausto

17 Ingmar Bergman retira do Apocalipse de S. João (Ap. 8,1 - 9,21) o título para o seu filme.

18 Sobre o tema do mal Anselmo Borges escreveu recentemente uma crónica, que aconselhamos a sua leitura, intitulada “A pandemia. Onde está Deus", Diário de Notícias, 20 de junho de 2020. Consultado em https://www.dn.pt/edicao-do-dia/20-jun-2020/a-pandemia-onde-esta-deus-12328663.html. Para um desenvolvimento do tema, entre uma vasta literatura especializada, consulte-se as seguintes obras: Eugen Drewermann (1977). Strukturen Bösen. Die jabwistische Urgeschichte in exegetischer Sicht. 3 vol(s). Paderbon: Verlag Ferdinand Schöningh e Paul Ricœur (2002). Philosophie de la volonté. II Finitude et culpabilité. Paris: Aubier, especialmente livre II - La Symbolique du Mal, p. 163-477. 
(1926), e pelo Sétimo Selo de Bergman, onde um cavaleiro (Max von Sydow) regressado das Cruzadas ao seu país natal (a Suécia medieval ainda que simplificada) é visitado pela Morte (já uma outra simbolização de uma das facetas do Mal: capa e capuz negros, foice, rosto branco, impávido e sombrio) a quem o Cavaleiro (símbolo da fé em Deus) desafia para uma derradeira partida de xadrez: "Enquanto eu resistir, eu sobrevivo// Se eu ganhar você me liberta" diz o Cavaleiro à Morte. Depois deste breve, mas tão decisivo, encontro com a Morte, o Cavaleiro prossegue o seu caminho por uma Suécia moribunda porque devastada pela Peste Negra, também conhecida pela Peste Bubónica ou pela Grande Peste, que foi a terrível pandemia que flagelou a Europa entre os anos de 1347 e 1351. Face a tão sinistro e horrendo flagelo (encarado como um castigo ou punição divina pelas gentes desesperadas), o Cavaleiro, sem disso o saber, confessa-se ironicamente à própria Morte, admitindo a sua crise de fé de um modo pungentemente assustador: "Eu choro para Ele no escuro, mas parece não ter ninguém lá (...) Eu quero tirá-Lo do meu coração. (...) Porque não posso matar Deus dentro de mim? (...) O que será de nós que queremos acreditar, mas não podemos?”. Noutra passagem do filme, o Cavaleiro dialogando com Mia, a mulher do saltimbanco Jof, diz-lhe de modo atormentado: "A fé é uma aflição dolorosa. É como amar alguém que está no escuro e não sai quando se chama”. Entrementes, o Cavaleiro é testemunha de toda a espécie de desgraças, de desventuras e de sofrimentos e, por conseguinte, vai-se dando conta de que a vida na terra não só é sofrimento como tremendamente absurda, semelhando-se àquela que hoje vivemos: uma vida alucinada e fantasmagórica à semelhança do cortejo dos flagelados penitentes que procuravam através de atos, incensos, cânticos e preces, esconjurar a maldição da peste.

Noutro momento do filme, numa conversa passada na taverna, ouvem-se as seguintes palavras que atestam bem que o estado emocional e de espírito da medievalidade sueca, no tocante à expressão de sentimentos profundos, não difere dos tempos presentes: "As pessoas estão loucas. Fogem e levam a peste para onde vão: "Todos nós sabemos, mas ninguém tem coragem de dizer"; "Todos estão mortos de medo"; "Você está com medo? Claro que estou” e, por último, “O dia está chegando”! Como pode o existir ser tão incomensuravelmente desolador, ser tão medonhamente sinistro e cruel, tão sem sentido, tão carente de significado? Assim o parece! Um existir sem significado 
nos altos céus e tão indiferente nas terras infernais! Ainda alguém quer o Homem? Há ainda alguém que se importe com o seu destino? Talvez "O Demónio da Depressão" (para usar o título de Andrew Solomon - 2001), talvez a Morte se ela própria não estiver demasiado ocupada jogando novas e necrófilas partidas de xadrez com vitórias ganhas antecipadamente a desencantados da fé! Também nunca esquecendo que a pandemia viral está sempre solícita para dançarmos com ela, à semelhança da última cena do $S e ́-$ timo Selo em que a morte dança com alguns dos principais personagens até à exaustão cadavérica.

\section{O SEM MUNDO DIANTE DE NÓS: NA COMPANHIA DE ALBERT CAMUS}

A expressão premonitória de "sem mundo" devemo-la a Günther Anders"19, ainda que a utilizemos num sentido diferente daquele que foi usado pelo autor ${ }^{20}$. Usámo-la para indicar que a peste, que nestes tempos sombrios nos contamina, esvaziou, esventrou o nosso mundo. Numa palavra, roubou-nos aquele mundo que era o nosso mundo habitual, com os seus rituais e rotinas. Muitos nesse mundo,

19 É uma parte do título Mensch obne Welt. Schriften zur Kunst und Literatur (1984) que na sua obra, cuja tradução é a de Homem sem Mundo. Escritos sobre Arte e Literatura, está indissociavelmente ligado a uma outra das suas obras, talvez a mais conhecida, intitulada Die Antiquiertheit des Menschen (1956 - Vol. 1 - 1980 - Vol. 2) que foi traduzida, não existe ainda tradução portuguesa, pelo sugestivo e importante título $A$ Obsolescência do Homem.

20 Leiam-se as palavras do autor a este respeito que retiramos da tradução espanhola de modo a agilizar a leitura por parte do leitor não familiarizado com a língua alemã: "Tenia razón el jovem descalzo al que yo, hijo burgués de la misma edad, allà por 1910 vi delante del restaurante elegante en Breslau, y que aplastaba su nariz contra el cristal para tratar de ver qué ocurria allí dentro y al que el policia alejaba a empujones com la pregunta 'Qué se há pedido aqui?', a la que, mientras tropezaba, respondia 'Nada!': ese joven realmente tenía razón, pues allí nada se le habia perdido, ya que antes no tenía nada que pudiera perder. Su 'ser' no era ciertamente ningún 'ser-en-el-mundo', sino precisamente un quedarse fuera o, como, como dije cincuenta años antes en el análisis de $\mathrm{Kafka} \mathrm{(...)} \mathrm{un} \mathrm{no-haber-sido-admitido-en-el-mundo.} \mathrm{Esta} \mathrm{fórmula} \mathrm{demuestra} \mathrm{lo} \mathrm{adecuado} \mathrm{que} \mathrm{es}$ el título de mi libro, pues este joven era realmente un 'hombre sin mundo. (...) Brevemente mis textos siguen tratando de los parados como 'hombres sin mundo'. A ellos, portadores de la consigna 'non laboro ergo non sum', los considero, junto con los aparatos, las figuras clave de nuestra época, los símbolos y representantes de la 'obsolescencia del hombre'. Y por eso han acompañado casi sin tregua mi pensamiento filosófico desde hace aproximadamente sesenta años” (2007, p. 14-15). 
do antes da pandemia, eram felizes e não sabiam que o eram, encontrando-se hoje como náufragos à deriva com os olhos postos num milagre que tarda em chegar. Haverá, pois, algo de mais fatal para a alma humana do que esperar sem esperança? Toda a espera sem esperança não é só uma ruína existencial ou ontológica, mas também uma morte anunciada, sempre desenrolada nos maiores sofrimentos e horrores! São estes sofrimentos e horrores que o flagelo da peste vírica causa nas suas vítimas que primeiramente os sofrem e depois ficam na sua lembrança: uma lembrança corroída de dor infinda e confundida com a loucura paralisante dos loucos mais loucos dos hospitais psiquiátricos-prisóes deste mundo, também este insano e à beira do abismo! Estas vítimas deserdadas do seu destino serão sempre conhecidas como os sobreviventes da peste:

É que nada é menos espetacular que um flagelo e, pela sua própria duração, as grandes desgraças são monótonas. Na recordação daqueles que viveram, os dias terríveis da peste não aparecem como grandes chamas intermináveis e cruéis, mas antes como uma marcha interminável que esmaga tudo na sua passagem. (...) Ninguém, entre nós, tinha já grandes sentimentos, mas toda a agente experimentava sentimentos monótonos (Camus, s. d., p. 198-199).

Silêncios partilhados de modo assustado à semelhança daqueles que atravessavam as entranhadas florestas de uma Grécia mítica sob a gritaria ruidosa e estridente de Pã, o protegido de Dioniso, também ele o deus ruidoso e tumultuoso. Não há um silêncio que seja adequado para ser vivido em tempos incertos, na medida em que o silêncio que importa, o silêncio interior, é sempre uma qualidade rara e única, própria de um regime da alta espiritualidade, que nunca se compagina com tempos sombrios e de incertezas múltiplas, de espaços corridos, de paisagens virtuais, de solidóes várias e de medos gélidos. Medos, vividos em solidão, que nos empurram para pensamentos depressivos, onde a morte e o suicídio nunca estão longe. É assim que o deus Pã aparece destilando o medo e o pânico, já não naqueles que atravessam o seu domínio de uma natureza agreste, mas em todos os que vivem como que emparedados, agoniadamente assustados nas suas casas, ou, por vezes, atravessando ruas quase desertas e silenciosas. Um silêncio estranho e nada comum, anunciador de tempestades varredoras de universos familiares, de esperanças e de memórias. O mais duro de suportar é este tipo 
de silêncio gélido, desencarnado e não abraçado: um tipo de silêncio que muito se estranha, que muito assusta, que muito pânico causa, mas que nunca apazigua, antes se entranha. Todos os sentimentos nos são roubados sem piedade, estrangulando a nossa disponibilidade de amar e de reconhecimento filiar daquele que é próximo. Nada pior do que sermos forçados ao exílio na nossa casa, entregues a recordaçôes e devaneios já tão despidos de emoções e de afetos: prisioneiros em terra própria e olhos teimosamente baixos de tão cansados de verem sofrimentos vários desfilando, enfim encalhados na desgraça, nas solidóes indesejadas e nos silêncios ensurdecedores porque escandalosamente insuportáveis: "A peste, é preciso dizê-lo, tirara a todos o poder do amor, e até o da amizade. Porque o amor exige um pouco de futuro e, para nós, já não havia senão instantes" (Camus, s. d., p. 200).

O silêncio mudo e avassalador, involuntário, assusta e é temido pelo habitante das sociedades contemporâneas, intrinsecamente ruidosas, que, de vários modos, sempre o excomungaram a favor da utopia de uma comunicação total e de uma tagarelice nervosa e despida de sentido reflexivo. O silêncio ensurdecedor das ruas desertas, o sofrimento solitário dos contaminados e o pânico dos ainda não-contaminados, a ansiedade, a angústia em crescendo, a desolação infinda, os rostos transidos de medo desfigurando-se à medida que o tempo infestado se prolonga numa incerteza crescente e arruinadora no interior das relaçóes intersubjetivas, que à semelhança de um grito estridente, tudo arrasta e tudo destrói à sua passagem, particularmente a esperança de que vamos ficar todos bem um dia. O pesadelo pestilento parece estar sempre longe e mesmo que chegasse nunca poderia durar muito, porque vencido pelos novos hércules da ciência e pelos gritos raivosos dos trans-humanistas, quais vendedores de quimeras tresloucadas senão mesmo diabólicas. Por isso, há muitos que têm tanta dificuldade em acreditar que o flagelo possa bater à porta de uma humanidade supostamente tão protegida pela biotecnologia medicinal. Por outras palavras, daqueles que acreditam no milagre trans-humanista e na ilusão, tão doce como perversa, de que a ciência tudo pode na velha tradição iluminista de um Helvétius:

eram humanistas [refere-se aos concidadãos]: não acreditavam nos flagelos. $\mathrm{O}$ flagelo não está à medida do Homem: diz-se então que o flagelo é irreal, que é um sonho mau que vai passar. Ele, porém, não passa e, de mau sonho em mau 
sonho, são os homens que passam, e os humanistas em primeiro lugar, pois não tomaram as suas precauções. Os nossos concidadãos não eram mais culpados do que os outros. Apenas se esqueciam de ser modestos e pensavam que tudo ainda era possível para eles, o que pressupunha que os flagelos eram impossíveis. Continuavam a fazer negócios, preparavam viagens e tinham opinióes. Como poderiam ter pensado na peste, que suprime o futuro, as viagens e as discussões? Julgavam-se livres, e nunca alguém será livre enquanto existirem flagelos (Camus, s. d., p. 49-50).

Uma peste voraz e avassaladora que se estende até à intimidade de um eu e de um nós, enterrando-se cruelmente nas nossas entranhas mais profundas e deixando-nos numa solidão sem fim...! Todo um flagelo e um silêncio frio que reenvia para a futilidade e vazio de uma existência vivida sem sentido numa "Idade de Ouro", senão mesmo um novo Éden, com a promessa de felicidade universal e de uma certa imortalidade que lhe estão associadas, que agora se vieram a revelar tão ilusórias como necrófilas. Uma "Idade de Ouro" que fez da santa aliança, forjada entre o tecno-capitalismo (eventualmente “capitalismo numérico [leia-se digital]”, na designação de José Gil) e a tecnociência, a sua pedra angular e o seu cântico de sereia mortal! Enfim, uma "nova religião", filiada numa crença no progresso ilimitado e na perfetibilidade indefinida do humano, que em tempos de globalização e de neoliberalismo oferecia e prometia uma felicidade universal, na condição de os novos crentes cultivarem a indiferença, o egoísmo, a divisão e o esquecimento de si e do Outro. Uma "nova religião" cujo reino era uma nova "Metrópolis" (recordando o clássico e tão atual filme de Fritz Lang, de 1927) unidimensional, bio tecnologizada, totalitária, sem amor e sem esperança!

Num tempo farto de abundâncias tão diversas como espalhafatosas, dominado pela omnipresença e omnipotência dos seus deuses tecnológicos e científicos (utopia tecnológica e digital, inteligência artificial, hiperconsciência digital ... $)^{21}$, da sua quase invencibilidade económica e industrial, as sociedades atuais viram-se repentinamente assoladas pelo flagelo de uma peste pandémica, causada por um novo e mortífero coronavírus, que praticamente surpreendeu e paralisou a sociedade global: "Os flagelos,

21 Lembramos a este respeito o estudo de Jorge dos Reis Bravo intitulado A Pandemia como pretexto da República Tecnodigital. Revista do Ministério Público. № Especial COVID-19, 2020, p. 475-499). 
com efeito, são uma coisa comum, mas acredita-se dificilmente neles quando nos caem sobre a cabeça. Houve no mundo tantas pestes, como as guerras, encontram sempre as pessoas igualmente desprevenidas" (Camus, s. d., p. 49). Uma peste que não é só vivida clinicamente, como também, e não é de somenos importância, ao nível do imaginário e das emoçôes, tanto individuais como coletivas. Deste modo, urge dizê-lo bem alto: se uma peste enquanto abstração pode ser monótona, já a agonia dos moribundos, o cortejo dos pestilentos e os gritos de dor, a pintam de cores inesquecíveis na memória dos sobreviventes.

\section{DAQUILO QUE APRENDEMOS: OS "JOGOS AMARGOS DA RECOR- DAÇÃO”(ALBERT CAMUS)}

O tipo de imaginário inspirado pela doença, denominada COVID-19, é do tipo apocalíptico e escatológico. Daí não seja de admirar que se trate de um imaginário passível de produzir temores, pavores e monstros arcaicos que inelutavelmente acabam por ferir um consciente já contaminado pelo medo e pânico, assim como por um pessimismo trágico que sempre bate à porta em momentos de crise e de vivência de fim do mundo. Uma infeção, como sabemos, não é somente vivida clinicamente (nível da consciência - esfera diurno). Ela é também, e muito enfaticamente, ficcionada, mitologizada (nível do inconsciente individual e coletivo - esfera noturna). A peste que nos assola e nos contamina tem sempre o seu quê de irreal, parece sempre um pesadelo que maquiavelicamente persiste em assombrar-nos: "E ainda depois de o doutor Rieux ter reconhecido perante o seu amigo, que um punhado de doentes acabavam, sem prevenir, de morrer da peste, o perigo continuava irreal para ele” (Camus, s. d., p. 50).

Trata-se de uma peste encarada e vivida como uma pandemia mortífera e como uma obsessão maléfica de tal amplitude que tudo o demais seja por si sepultado e esquecido. Tão esquecida que a sociedade da opulência tecnológica, económica, envolvida pelos cânticos transhumanistas de vários matizes, pareceu, pelo menos aparentemente, não só ter esquecido a lição e a memória de todo um complexo de vírus responsável por muitos dos surtos mais destrutivos dos últimos cem anos (as gripes de 1918, de 1957 e de 1968; a SARS, a MERS e a Ébola), como também os valores da compaixão pelo próximo, da escuta, da generosidade, da gratidão, da tolerância, da esperança, da empatia, da 
prudência, da responsabilidade, da paz, entre outros. Ao iludir-se com a imortalidade e de que o homem seria eternamente um novo deus na terra (os velhos mitos de Prometeu e de Ícaro), a humanidade esqueceu inadvertidamente o chão que pisa e a sua consequente fragilidade de que "do pó viemos e ao pó voltaremos" (Gn. 3, p. 19).

$\mathrm{Na}$ verdade, temos que fazer desta vivência trágica uma ocasião de redenção lúcida, a fim de não cairmos permanentemente na armadilha de que "tudo vai ficar bem" pela simples razão de que é essa mesma ilusão que contribuirá fatalmente para a nossa perdição! Por isso, torna-se assim imperativo compreender que nada ficará como dantes, não vamos ficar bem, tudo será diferente ao ponto de, muito provavelmente, a existência não passar de um trágico simulacro e isto, por si só, não deixar de ser francamente aterrador:

A única coisa que é evidente é que o vírus irá arrasar os alicerces das nossas vidas, provocando não só uma quantidade exorbitante de sofrimento, como um caos económico possivelmente pior do que o da Grande Recessão. Não há regresso à normalidade, o novo 'normal' terá de ser construído a partir das ruínas das nossas vidas antigas, ou daremos por nós numa nova barbárie cujos indícios já são nitidamente visíveis. (...) teremos de colocar a questão fundamental: o que está errado no nosso sistema para termos sido apanhados desprevenidos por esta catástrofe, apesar de os cientistas estarem há anos a alertar-nos para a sua possibilidade? (Žižek, 2020, p. 12-13).

Naturalmente que estas mudanças, aceites ou não, arrastarão consigo consequências ainda difíceis de antever na hora atual e que admitimos não irão afetar todos de igual modo. Por tudo aquilo que viemos a escrever, particularmente retomando o nosso título, um tempo que atualmente vivemos, fustigado por um tão terrível flagelo, acentua em nós um sentimento trágico de deserdados, de orfandade de uma Esperança, ainda que ténue. A este respeito, recordando o mito de Pandora com sua famosa caixa ou jarro, estamos condenados sim, a receber antes todos os males que dessa caixa escaparam, incluindo a peste que agora nos contamina tiranicamente, exceto ao seu 
antídoto, o da Esperança ${ }^{22}$. Uma Esperança redentora e salvífica que, à semelhança do Santo Graal, poderia transmutar, recordando um dos textos emblemáticos de Sören Kierkegaard, esta nova peste negra em "lírios do campo e em aves do céu"! E se tal acontecesse, desejamo-lo mais do que o esperamos, seria uma ocasião rara para espreitar por cima dos altos muros desta monumental crise e, pelo menos, tentarmos reinventar a nossa condição humana tão em queda e tão em perigo. Uma reinvenção comprometida em mudar de paradigma que afinasse, como o pretende Hans Jonas, o agir humano com uma ética da responsabilidade. Pois só assim poderemos eventualmente merecer ainda ter mundo, e não um "sem mundo", que certamente nos despedaçaria à semelhança do génio maléfico que nos atormenta. Sob as garras deste génio não só ficamos sem mundo como também ficamos desfigurados face a nós e ao Outro! Uma humanidade transformada numa sombra pálida e descarnada à semelhança dos rostos do vampiro Drácula, de Mephisto e da própria Morte tal como a visualizamos no Sétimo Selo de Bergman.

Por fim, recordamos que somos todos prisioneiros de um vampiro vírico que enterra carnivoramente em nós os seus dentes pontiagudos, transformando-nos numa espécie de vivos-mortos atordoados e alucinados, vagueando pelas noites fora, acorrentados e muitas vezes puxados pela própria Morte! E esta, à semelhança de Mephisto, também faz seus pactos, como por exemplo o pacto com o Cavaleiro, mas o seu forte mesmo é arrastar-nos consigo até às entranhas ardentes e fumegantes do reino de Hades, sempre ávido de receber no seu seio o sangue de inocentes ainda de olhares esperançosos! Tanto Fausto como o Cavaleiro perderam a sua fé porque, nas palavras deste último, "Nenhum homem pode viver com a Morte e saber que tudo é nada"

22 O principal motivo da criação de Pandora (que significa todos os dons), segundo a mitologia greco-romana, seria um castigo enviado por Zeus pelo facto de Prometeu ter roubado o fogo divino do monte Olimpo para partilhá-lo com a raça humana. Zeus ao criar Pandora ofereceu-lhe uma caixa (seria antes um jarro ou um vaso fechado) que estaria guardada, mediante um pedido do seu irmão (Prometeu), pelo seu esposo Epimeteu. Porém, Pandora, devorada pela curiosidade estimulada por Hermes, convenceu-o a deixá-la abrir onde todos os males estavam guardados. Depois de aberta, esses mesmos males espalharam-se por toda a terra causando toda a espécie de infelicidades e de tormentos a uma humanidade já agoniada. Nesse momento, Pandora, apercebendo-se da sua funesta atitude, fechou-a apressadamente, restando na caixa apenas a esperança a fim de reconfortar o género humano. 
porque fatalmente “a vida é um terror sem sentido". E uma vida assim não merece, na verdade, ser vivida! Salvo se uma voz salvífica, como a que provém do fundo do Graal, nos advertir: "Haja o que houver//Espero por ti//Eu sei, eu sei” (Letra dos Madredeus, "Haja o que houver”, do álbum "O Paraíso", 2009). Um ti ainda que fosse a Esperança resgatada do fundo da Caixa de Pandora! Pela simples razão que queremos acreditar, na companhia de Slavoj Žižek, não merecer o castigo dela nos privar pela ação maligna de algum coronavírus, nomeadamente aquele que atualmente nos inferniza ${ }^{23}$.

\section{BIBLIOGRAFIA CONSULTADA}

AA.VV. (1986). Décadence et Apocalypse. Cabier no 1. Dijon: Université de Bourgogne.

Agamben, G. (2020). Reflexiones sobre la peste. In Amadeo, P., Sopa de Wuan (pp. 135-137). S/. Local: Aspo. Consultado em https://bit.ly/sopadewuhan.

Amadeo, P. (2020) (Ed.). Sopa de Wuhan. S/. Local: Aspo. Consultado em https://bit.ly/sopadewuhan.

Anders, G. (2007). Hombre sin Mundo. Escritos sobre arte y literatura. Trad. de Josep Monter Pérez. Valencia. Pre-Textos.

Anders, G. (2011). La Obsolescencia del Hombre. Vol. I - Sobre el alma en la época de la segunda revolución industrial. Trad. de Josep Monter Pérez. Valencia. Pre-Textos.

Anders, G. (2011ª). La Obsolescencia del Hombre. Vol. II - Sobre la destrucción de la vida en la época de la tercera revolución industrial. Trad. De Josep Monter Pérez. Valencia. Pre-Textos.

Baudouin, C. (1993). L'œuvre de Jung. L'euvre de Jung et la psychologie complexe. Paris: Payot.

23 Sobre o sentido destas palavras, remetemos o leitor para a obra do próprio autor intitulada $A$ Pandemia que Abalou o Mundo, 2020, Introdução, Noli Me Tangere, p. 11-13. Uma Esperança que, aliás, o filme Contágio (no original em inglês, Contagion) de Steven Soderbergh, realizado em 2011, cuja temática não pode ser mais atual, anuncia com a descoberta de uma vacina no contexto de uma gravíssima pandemia à semelhança daquela que estamos a atravessar. O enredo do filme trata da propagação de um vírus e das tentativas de pesquisadores, médicos e funcionários de saúde pública para identificar e conter a doença. À medida que a pandemia alastra, vai-se assistindo ao desmoronamento da ordem social com todas as consequências nefastas que isso acarreta, tudo é feito para que se descubra uma vacina que impeça a propagação letal do vírus e que, por conseguinte, se consiga salvar a humanidade. Nota do autor: devemos esta informação fílmica, que muito agradecemos, ao Senhor Dr. Carlos Alberto Videira (Diretor do Departamento de Desporto e Cultura dos Serviços de Ação Social da UMinho). 
Bravo, J. dos R. (2020). A Pandemia como pretexto da República Digital. Revista do Ministério Público. № Especial COVID-19, 475-499.

Brun, J. (1990). Philosophie de l’histoire. Les promesses du temps. Paris: Stock.

Camus, A. (s. d.). A Peste. Trad. de Ersílio Cardoso. Lisboa: Edição Livros do Brasil.

Defoe, D. (1966 [1722]). A Journal of the Plague of Year. Harmondsworth, Middlesex: Penguin Books.

Delumeau, J. (1997). Mil anos de felicidade. Uma história do paraiso. Trad. de Augusto Joaquim. Lisboa: Terramar.

Drewermann, E. (1977). Strukturen Bösen. Die jabwistische Urgeschichte in exegetischer Sicht. 3 vol(s). Paderbon: Verlag Ferdinand Schöningh.

Dumas-Reungoat, C. (2001). La Fin du Monde. Enquête sur l'origine du mythe. Paris : Les Belles Letres.

Ferry, L. (2016). La révolution transhumaniste : comment la technomédecine et l'uberisation du monde vont bouleverser nos vies. Paris: Plon.

Foessel, M. (2012-2019). Après la fin du monde. Critique de la raison apocalyptique. Paris : Éditions du Seuil.

Franco, J. E. \& Fernandes, J. Manuel (1999). O Mito do Milénio. Lisboa: Paulinas.

Guattari, F. (1989). Les trois écologies. Paris: Éditions Galilée.

Guimarães, A. R., Araújo, A. F., Ribeiro, J. A. \& Almeida, R. de (2015). Olbares sobre Frankenstein: literatura, educação e cinema. São Paulo: Képos; Raleigh: Lulu Press.

Hillman, J. (2015). Pã e o Pesadelo. Trad. de Carla C. Pilon e de Daniel F. Yago. São Paulo: Paulus.

Jung, C. G. (1937). Le Moi et l'Inconscient. Trad. par A. Adamov. Paris: Gallimard.

Jung, C. G. (1965). L'Ame et La Vie. Trad. de Roland Cahen e Yves Le Lay. Paris: Buchet/Chastel.

Marigny, J. (1999). Um vampiro renasce das suas cinzas. In: Marigny, J. (dir.de). Drácula (pp. 9-70). Trad. de Fernando Antunes. Lisboa: Editora Pergaminho.

Menegaldo, G. (1998). O ecrã negro dos nossos terrores. In: Marigny, J. (dir.de). Drácula (pp. 91-117). Trad. de Fernando Antunes. Lisboa: Editora Pergaminho.

Ricour, P. (2002). Pbilosopbie de la volonté. II Finitude et culpabilité. Paris: Aubier.

Sironneau, J.-P. (1980). Retour du mythe et imaginaire socio-politique. In AA.VV. Le Retour du Mythe (pp. 9-28). Grenoble. PUG.

Sironneau, J.-P. (2000). Métamorphoses du Mythe et de la Croyance. Paris: L'Harmattan.

Stoker, B. (2014). Drácula. Trad. de Filipa Aguiar. Alfragide: edições ASA II. 
Wallace-Wells, D. (2019). A Terra Inabitável. Como vai ser a Vida pós-Aquecimento Global. Trad. de João Carlos Silva. Alfragide: Lua de Papel.

Žižek, S. (2020). A Pandemia que Abalou o Mundo. Trad. de João Moita. Lisboa: Relógio D’Água Editores. 